\title{
MORPHOLOGY AND MORPHOMETRY OF THREE Plasmodium juxtanucleare (APICOMPLEXA: PLASMODIIDAE) ISOLATES*
}

\author{
CARINA ELISEI'; KÁTIA, R. FERNANDES²; MARIA D. FORLANO ${ }^{3}$; RENATA C. MADUREIRA²; ALESSANDRA \\ SCOFIELD $^{4}$; KARLA S. C. YOTOKO ${ }^{5}$; CLEBER O. SOARES ${ }^{1}$; FLÁBIO RIBEIRO ARAÚJO' ${ }^{1}$; CARLOS L. MASSARD ${ }^{6}$
}

\begin{abstract}
ELISEI C.; FERNANDES, K.R.; FORLANO, M.D.; MADUREIRA, R.C.; SCOFIELD, A.; YOTOKO, K.C.; SOARES C.O.; ARAÚJO, F.R.; MASSARD C.L. Morphology and morphometry of three Plasmodium juxtanucleare (Apicomplexa: Plasmodiidae) isolates. [Morfologia e morfometria de três isolados de Plasmodium juxtanucleare (Apicomplexa: Plasmodiidae)]. Revista Brasileira de Parasitologia Veterinária, v. 16, n. 3, p. 139-144, 2007. Laboratório de Biologia Molecular Sanidade Animal, Embrapa Gado de Corte, Campo Grande, MS, Brasil.E-mail: carinaelisei@yahoo.com.br

In this work, three isolates of Plasmodium juxtanucleare have been analyzed based on morphological, morphometric and parasitic parameters. Each isolate was sampled from naturally infected adult chicken (Gallus gallus) from rural areas of three Brazilian municipalities: Seropédica (22 $48^{\prime} \mathrm{S}$; $43^{\circ} 41^{\prime} \mathrm{W}$ ), in the state of Rio de

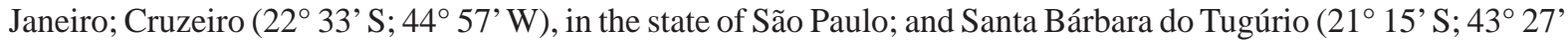
W), in the state of Minas Gerais. The blood samples taken from each infected chicken were inoculated in three groups of ten young chicken (21 days old). Blood smears of the experimentally infected chicken were sampled every two days until the 69th day in order to evaluate the parasitemia. For the morphological-descriptive and morphometric analyses, we measured 30 individuals from each of the intraerythocytic states, measures of the major (MD) and minor diameters (md), the estimation of morphometric index (Mi=md/MD) and size (T=pab, a=md/2; $\mathrm{b}=\mathrm{MD} / 2$ ). The results indicated low and homogeneous parasitemia rates in the three strains, which showed differences among shape and size of the parasitic stadia displayed.
\end{abstract}

KEY WORDS: Plasmodium juxtanucleare, experimental infection, Gallus gallus, avian malaria.

\section{RESUMO}

Neste trabalho, três isolados de Plasmodium juxtanucleare foram analisados com base na morfologia, morfometria e parâmetros parasitológicos. Cada isolado foi coletado de aves (Gallus gallus) adultas infectadas naturalmente de áreas rurais de três municípios brasileiros: Seropédica (22 $2^{\circ} 48^{\prime}$ S; $43^{\circ} 41^{\prime}$

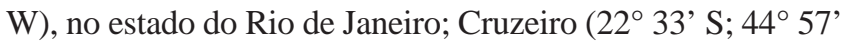
W), no estado de São Paulo; e Santa Bárbara do Tugúrio (21ำ

\footnotetext{
* Supported by CNPq.

${ }^{1}$ Laboratório de Biologia Molecular Sanidade Animal, Embrapa Gado de Corte, Campo Grande, MS. E-mail: carinaelisei@yahoo.com.br

${ }^{2}$ Curso de Pós-Graduação em Ciências Veterinárias, Departamento de Parasitologia Animal (DPA), Universidade Federal Rural do Rio de Janeiro (UFRRJ), Seropédica, RJ 23890-000.

${ }^{3}$ Departamento de Salud Pública, Área de Parasitologia Veterinaria, Nucleo Dr. Hector Ochoa Zuleta, Universidad Centroccidental "Lisandro Alvarado" UCLA. Cabudare- Barquisimeto- Lara, Venezuela;

${ }^{4}$ Curso de Medicina Veterinária, Universidade Federal do Pará, Campus Castanhal.

${ }^{5}$ Pontifícia Universidade Católica do Rio Grande do Sul (PUC-RS), Porto Alegre, RS.

${ }^{6}$ DPA/UFRRJ, Seropédica, RJ 23890-000. E-mail: massard@ufrrj.br
}

$15^{\prime}$ S; $43^{\circ} 27^{\prime}$ W), no estado de Minas Gerais. As amostras de sangue coletadas de cada ave infectada foram inoculadas em três grupos de dez aves (21 dias de idade). Esfregaços sangüíneos das aves infectadas experimentalmente foram realizados de dois em dois dias durante um período de 69 dias para avaliar a parasitemia. Para análises morfofisiológica e morfométrica, foram mensurados 30 indivíduos de cada estágio intraeritrocítico. Foram tomadas as medidas do diâmetro maior (DM) e diâmetro menor (dm), com os quais foi estimado o índice morfométrico (Mi=md/MD) e o tamanho ( $\mathrm{T}=\mathrm{pab}, \mathrm{a}=\mathrm{md} /$ 2; b=MD/2). Os resultados indicaram uma parasitemia homogênea entre os três isolados, havendo diferenças apenas nas formas e tamanhos dos estádios parasitários.

PALAVRAS-CHAVE: Plasmodium juxtanucleare, infecção experimental, Gallus gallus, malária.

\section{INTRODUCTION}

Among the hematozoans, Plasmodium (Novyella) juxtanucleare Versiani and Gomes, 1941 is the only malarial parasite that naturally infects individuals of Gallus gallus in 
Brazil (VERSIANI; GOMES, 1941, 1943; KRETLLI, 1972; MASSARD, 1976). The parasited birds way present variable symptoms such as of lack of appetite, anemia, digestive and neurological disturbances, somnolence and pallid combs (ALDABAGH, 1961; SOARES et al., 1995; SOUZA, 1998). Study conducted at egg farms showed that those hens infected by $P$. juxtanucleare produce less than those not infected (MASSARD, 1982). In most cases, malaria caused by this parasite is only a secondary and asymptomatic illness (BELTRAN, 1943; KRETTLI, 1972; MOTA et al., 1998). Nevertheless, the association with other infectious agents might be a complicating factor and can even lead to death of the birds (AL-DABAGH, 1961).

The identification of the species of malaria parasites has been frequently based on morphological characteristics of the intraerythocytic stages (MANWELL, 1936). This probably led to precocious description of various new species of Plasmodium, which might be only plastic varieties of previously described species (MANWELL, 1936; VAN RIPER III et al., 1994). In this sense, Ishiguro (1957) considered Plasmodium japonicum as a new species of domesticated chicken parasite, but Akiba (1959), based on biological and morphological characteristics, found that $P$. japonicum and $P$. juxtanucleare are the same species. Manwell (1943), in studies based on morphological characteristics, raised the hypothesis that $P$. nucleophilum (parasites of Passeriformes) and P. juxtanucleare could be the same species. Nevertheless, this author had found that experimental infection of $P$. nucleophilum in chicken support the validity of distinct species.

The current studies concerning $P$. juxtanucleare do not clarify the biology of this parasite in a complete way. There are doubts about its biological cycle in vertebrate and invertebrate hosts, and little is known about its morphological and morphometric characteristics. In this work, we described the intraerythocytic parasites forms of three $P$. juxtanucleare isolates regarding their morphological and morphometric aspects and some biological parameters, such as the prepatent period and peak of parasitemia, under experimental infection. We measured these characteristics and compared their variance in order to verify the existence of significant differences within a group of organisms infected experimentally by a single isolate and also among groups infected by different isolates.

\section{MATERIAL AND METHODS}

Three adult chicken (G. gallus) naturally infected with $P$. juxtanucleare were sampled from different rural areas: Seropédica, in the state of Rio de Janeiro $\left(22^{\circ} 48^{\prime} \mathrm{S}\right.$; $43^{\circ} 41^{\prime}$ W), Cruzeiro, in São Paulo (22 $33^{\circ}$ S; $44^{\circ}$ 57' W), and Santa

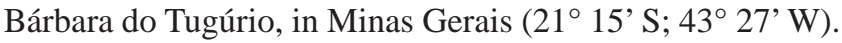
In order to raise the number of parasites in each individual, they received an intramuscular injection of $26 \mathrm{mg} / \mathrm{Kg}$ of methylprednisolone acetate (SOUZA, 1998) in the breast region (single dose) to suppress the immunological system. After that, the birds were accompanied and peripheral blood smears were prepared daily, until the 28th day, when $15 \mathrm{~mL}$ of the blood of each individual were extracted through radial puncture.

To measure the parasitemia, infection dynamics and parasite size and form, 40 one-day-old chicks of commercial laying lineage were acquired and kept in a covered enclosure protected against mosquitoes. At 21 days of age, the chicken were examined through blood smears and divided into four groups of ten chicks each. In three of these groups, each chick was inoculated, by intraperitoneal injection, with $1 \mathrm{~mL}$ of the infected blood of the infected chicken of Seropédica (Irj), Cruzeiro (Isp) and Santa Bárbara do Tugúrio (Img). The control group received $1 \mathrm{~mL}$ of physiological solution.

The parasitemia of the chicken in each group were accompanied by peripheral blood smears every two days, from the first to the 69th day after inoculation (DAI). The blood smears were fixed in methanol (methyl alcohol P.A. - Merck ${ }^{\circledR}$ ), air dried, stained with Giemsa (methyl blue eosin, Giemsa Merck ${ }^{\circledR}$ ) and observed under an optical microscope (Leitz Wetzalar - Dialux 20 EB) with a 10X eyepiece and 100X immersion objective lens.

Since most of the time each erythrocyte is infected by only one parasite, the number of parasites were counted by the number of infected erythrocytes in 100 homogeneous microscopic fields (SOUZA, 1998) of each blood smear (parasite density), and the parasitemia was calculated by multiplying this number by 100 and dividing it by 10,000 $(x * 100 / 10.000)$. During the count process, we also classified the intraerythocytic stage of each parasite.

For the morphological-descriptive and morphometric analyses, we measured 30 individuals from each of the intraerythocytic stadia (trophozoites, schizonts, macrogametocytes and microgametocytes). The measurements were taken from the blood smears with the highest parasite peak per isolate. During the morphometric analysis, we measured the major and minor diameters (MD and $\mathrm{md}$ ) of each parasite. For that, an ocular micrometer (Wild-pZo - 15x) was attached to the microscope. These measures were used to calculate the parasites morphometric index $(\mathrm{MI}=\mathrm{md} / \mathrm{MD})$ and size index $(T=p a b$, with $a=m d / 2$ and $b=M D / 2$, based on the formula for the area of an ellipse).

The statistical treatment of the data was done with variance analysis (ANOVA), to detect heterogeneity within and between samples. Since the data obtained were not normally distributed, a condition for use of parametric tests, $\log (x+1)$ correction was applied.

\section{RESULTS}

The naturally infected chickens of the states of Rio de Janeiro, São Paulo and Minas Gerais presented parasitemia of $0.03 \%, 0.01 \%$ and $0.04 \%$ respectively, before the administration of methylprednisolone acetate. After 28 days, the parasitemia has increased to $13.4 \%, 8.6 \%$ and $14.2 \%$, respectively, and the blood was extracted and inoculated into the three experimental groups studied here. The following results refer to the three experimental groups of chicken 


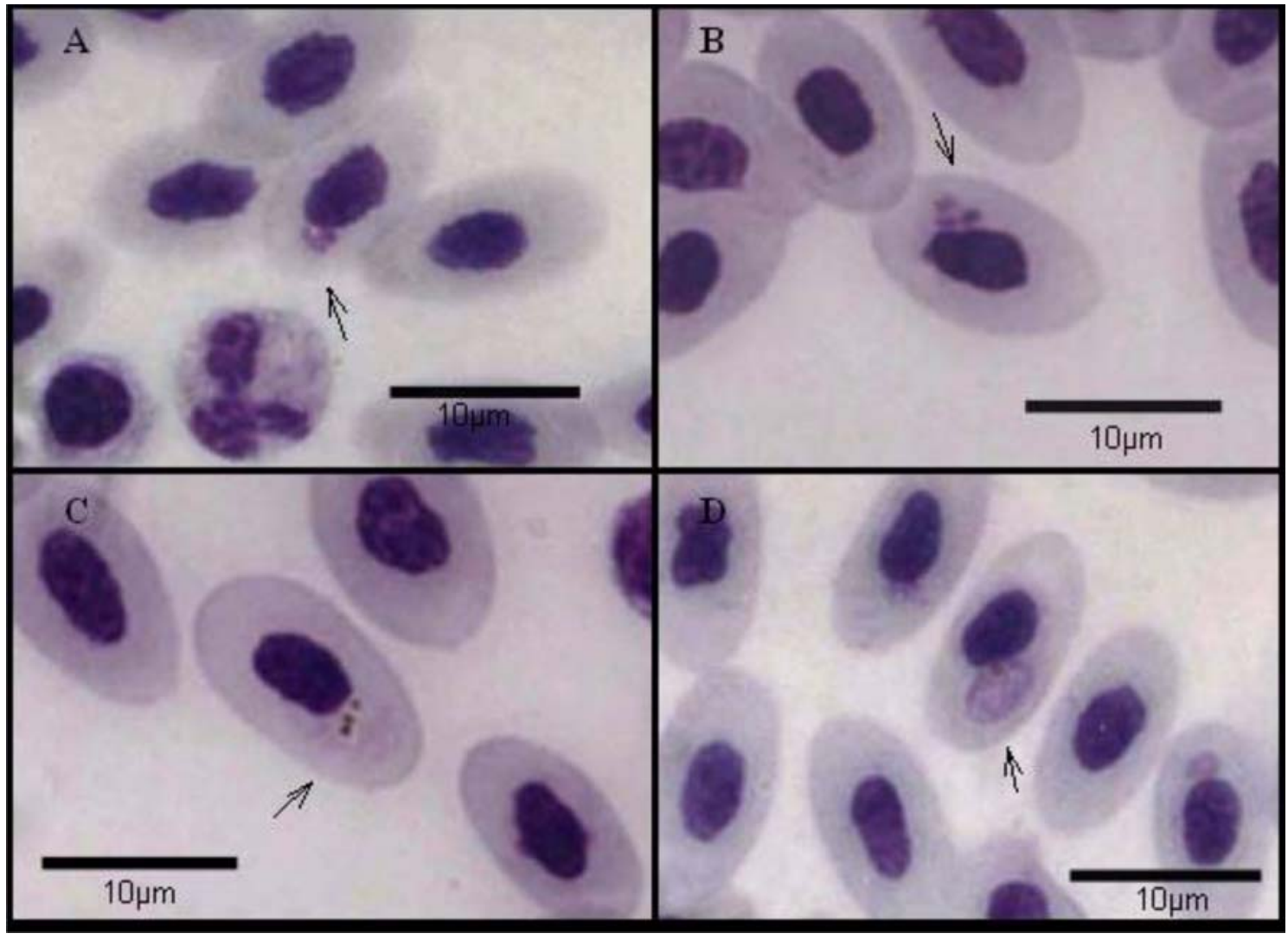

Figure 1. Different stadia of Plasmodium juxtanucleare. A- Young trophozoite $(\rightarrow)$, leukocyte $(\mathrm{I})$; B- Schizont containing three merozoites $(\rightarrow)$; CMicrogametocyte showing malarial pigments $(\rightarrow)$; D- Macrogametocyte showing malarial pigment $(\rightarrow)$. Giemsa, 1000X.

inoculated with three isolates of $P$. juxtanucleare: Irj, Isp and Img. The control group remained parasite free during the entire experiment, showing that the protection against infection by natural vectors was effective. Figure 1 shows the different stadia of P. juxtanucleare (Trophozoite, Schizont, Microgametocyte and Macrogametocyte).

The pre-patent period (PPP) of the experimental inoculation of the three $P$. juxtanucleare isolates was, on average, 14.2, 14 and 16.8 days in the Irj, Isp and Img isolates, respectively. The maximum parasitism (MP) occurred, on average, 45 days after inoculation (DAI) in Irj, 55 DAI in Isp and 45 DAI in Img (Figure 2). The parasitism for the three inoculates remained low, with some fluctuations within the

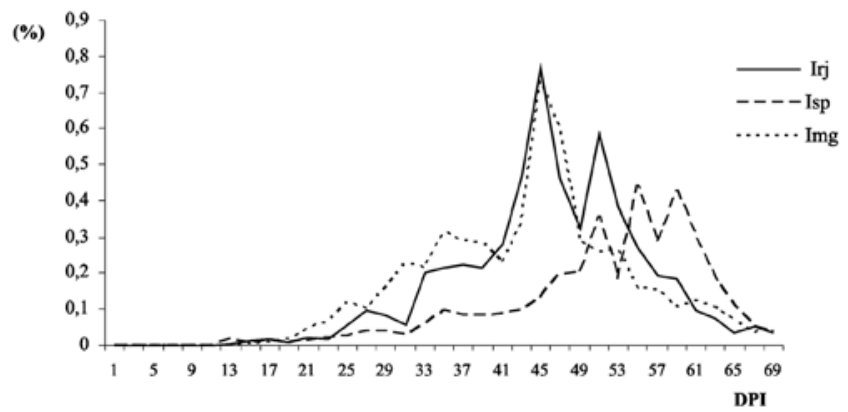

Figure 2. Parasitemia curve of different isolates of Plasmodium juxtanucleare. groups inoculated with the different isolates (Figure 2). Nevertheless, we found no significant differences among the parasite densities within $(\mathrm{P}>0.05)$ and among $(\mathrm{P}>0.05)$ the isolates, which averaged $4.8 \%$ (Table 1 ).

The mean trophozoite parasitemia of the Irj, Isp and Img isolates were, respectively, 3.41, 2.52 and 3.76; and we found no significant differences in the parasitemia of trophozoites within $(\mathrm{P}>0.05)$ and among $(\mathrm{P}>0.05)$ the isolates (Table 2). Within the parasite stadia, the trophozoites presented the largest number; a result previously obtained both in observations of natural (SOUZA, 1998; SANTOS-PREZOTO, 2004) and experimental infections (SOUZA, 1998; ELISEI, 2001). The mean parasitemia of the schizonts was 0.54 (Irj),

Table 1. Analysis of the parasite density among isolates of Plasmodium juxtanucleare, experimentally inoculated in chicks (Gallus gallus).

\begin{tabular}{ccccc}
\hline Isolate & $\begin{array}{c}\text { Number } \\
\text { of birds }\end{array}$ & Parasitemia $^{1}$ & Variance $^{2}$ & P- $^{\text {value }}{ }^{3}$ \\
\hline Irj & 10 & 5.09 & 33146.4 & 0.091875 \\
Isp & 10 & 3.43 & 26310.04 & \\
Img & 10 & 5.07 & 56744.94 & \\
\hline
\end{tabular}

${ }^{1}$ Mean parasitemia value of the raw data.

${ }^{2}$ Variance of the raw data.

${ }^{3}$ P-value of significance among the isolates (Irj, Isp and Img). Log $(x+1)$ transformed data. 
Table 2. Analysis of variance of the parasite density of the intraerythocytic stadia of the different isolates of Plasmodium juxtanucleare.

\begin{tabular}{cccccc}
\hline Parasite stadium & Isolate & $\begin{array}{c}\text { Number } \\
\text { of birds }\end{array}$ & $\begin{array}{c}\text { Parasi- } \\
\text { temia }^{2}\end{array}$ & Variance $^{3}$ & P-value $^{4}$ \\
\hline \multirow{2}{*}{ Trophozoite } & Irj & 10 & 3.41 & 14190 & \\
& Isp & 10 & 2.52 & 13952.77 & 0.155381 \\
& Img & 10 & 3.76 & 33168.89 & \\
Schizont & Irj & 10 & 0.54 & 365.1222 & \\
& Isp & 10 & 0.44 & 283.8222 & 0.506084 \\
& Img & 10 & 0.50 & 437.5111 & \\
Macrogametocyte & Irj & 10 & 0.66 & 536.9 & \\
& Isp & 10 & 0.25 & 152.322 & 0.000237 \\
& Img & 10 & 0.46 & 370.044 & \\
Microgametocyte & Irj & 10 & 0.48 & 746.8444 & \\
& Isp & 10 & 0.22 & 148.322 & 0.017962 \\
& Img & 10 & 0.35 & 265.3889 & \\
\hline
\end{tabular}

${ }^{1}$ Number of birds per isolate.

2 Mean parasitemia value of the raw data.

${ }^{3}$ Variance of the raw data.

${ }^{4} \mathrm{P}$-value of significance among the isolates (Irj, Isp and Img). Log $(x+1)$ transformed data.

0.44 (Isp) and 0.50 (Img), and there were no significant differences among the parasitemia of schizonts within $(\mathrm{P}>$ $0.05)$ and among $(\mathrm{P}>0.05)$ isolates (Table 2). From two to four merozoites per schizont were observed in the three isolates.

\section{Morphological and morphometric analysis}

The descriptive morphological analysis of the intraerythocytic parasite stadia of $P$. juxtanucleare from the different isolates (Irj, Isp and Img) revealed the presence of ovoid, ring-shaped, elliptical, piriform, ameboid and rounded forms, with ovoid and elliptical forms prevailing in all isolates. This result is similar to Bennett and Warren (1966), Kretlli
(1971), Massard and Massard (1981), Serra-Freire and Massard (1979), Massard (1982), Elisei et al. (2001).

The trophozoites presented significant differences in form (MI) and size (S) among the isolates. The schizonts did not have any significantly different forms in comparing the isolates, but there were size differences, which were on average greater in the group inoculated with Irj. The variance in the sizes was greatest in Img and smallest in Isp (Table 3).

Regarding the macrogametocytes and microgametocytes, only in the former we have detected significant differences in form among the groups studied. There were significant size differences among the groups in both parasite stadia (Table 3).

\section{DISCUSSION}

In this work, we measured three isolates of $P$. juxtanucleare for their morphometric characteristics and parasitemia indices. To avoid deviations due to the particularities of the original hosts, each isolate was inoculated in 10 experimental birds, and all the measurements were homogeneous in each host group studied, showing that the differences found are due to real differences among the isolates. Since we did not found any infection signal in the control group, we can conclude that the protection system used during the experiments was efficient against infection by natural vectors.

The morphometric analysis revealed significant differences of form (measured by the MI) among the isolates in the trophozoite and macrogametocyte stadia, while size differences were found in all parasite stadia (Table 3). These differences emphasize the need of the study of a larger number of samples, in order to reach a more complete scenario of the variation spectrum of this parasite, and avoid the miss description of new species. As an example, this kind of data, the description of P. japonicum (ISHIGURO, 1957) could be avoided. On the other hand, the morphometric measurements of $P$.

Table 3. Analyses of variance of the form and size of the parasite stadia of different isolates of Plasmodium juxtanucleare

\begin{tabular}{|c|c|c|c|c|c|c|c|c|}
\hline \multirow[t]{2}{*}{ Parasite stadia } & \multirow[t]{2}{*}{ Isolate } & \multirow{2}{*}{$\begin{array}{r}\text { Total } \\
\text { forms }\end{array}$} & \multicolumn{3}{|c|}{ Form $^{1}$} & \multicolumn{3}{|c|}{ Size $^{2}$} \\
\hline & & & Mean & Variance $^{3}$ & P-value ${ }^{4}$ & Mean & Variance $^{3}$ & P-value ${ }^{4}$ \\
\hline \multirow[t]{3}{*}{ Trophozoite } & Irj & 30 & 0.629456 & 0.014961 & & 7.85365 & 1.07022536 & \\
\hline & Isp & 30 & 0.724336 & 0.008361 & 0.003724 & 7.76701 & 0.36330676 & 1.15857E-05 \\
\hline & Img & 30 & 0.649399 & 0.014416 & & 6.89563 & 0.5119214 & \\
\hline \multirow[t]{3}{*}{ Schizont } & Irj & 30 & 0.648018 & 0.017647 & & 8.720518 & 0.620461 & \\
\hline & Isp & 30 & 0.68764 & 0.017076 & 0.249213 & 8.081957 & 0.35775 & 0.01596 \\
\hline & Img & 30 & 0.703201 & 0.016792 & & 8.008951 & 1.008675 & \\
\hline \multirow[t]{3}{*}{ Macrogametocyte } & Irj & 30 & 0.630637 & 0.012573 & & 7.718697 & 0.907584 & \\
\hline & Isp & 30 & 0.616576 & 0.01712 & 0.001713 & 9.204205 & 1.472951 & 1.21512E-05 \\
\hline & Img & 30 & 0.721262 & 0.012666 & & 7.840659 & 0.943103 & \\
\hline \multirow[t]{3}{*}{ Microgametocyte } & Irj & 30 & 0.65044 & 0.017688 & & 13.1223 & 14.50797 & \\
\hline & Isp & 30 & 0.605643 & 0.017337 & 0.364941 & 12.16729 & 4.567154 & $1.618 \mathrm{E}-15$ \\
\hline & Img & 30 & 0.615296 & 0.014039 & & 6.895637 & 0.511927 & \\
\hline
\end{tabular}

${ }^{1}$ Morphometric index $(\mathrm{Ml}=\mathrm{md} / \mathrm{MD})$. Minor diameter $(\mathrm{md})$ and major diameter $(\mathrm{MD})$. Values in micrometers $(\mathrm{mm})$

${ }^{2}(\mathrm{~T}=\mathrm{pab}$, with $\mathrm{a}=\mathrm{md} / 2$ and $\mathrm{b}=\mathrm{MD} / 2)$

${ }^{3}$ Variances of raw data.

${ }^{4} \mathrm{P}$-value of significance among the isloates (Irj, Isp and Img). Data Log $(x+1)$ transformed. 
nucleophilum appear to be within the variation of $P$. juxtanucleare, but the maintenance of its status as a species was possible due to the characteristics of association with the host. Hence, other techniques of characterization, such as using molecular markers, could be useful in species identification. Besides this, since experimental hosts are theoretically homogeneous, one can infer that this variation is largely due to the intrinsic genetic variation of this type of characteristic.

Most of the parasitemia measures, particularly total parasitism (which after all can be used as a measure of the parasite's pathogenicity), showed that the three isolates are homogeneous. Nevertheless when they were separated into their components, only the parasite densities of the trophozoites and schizonts did not differ significantly among the isolates, while there were differences in the parasite densities of macro and microgametocytes. It is possible, however, that these differences rose due to problems of visual distinguing between macro and microgametocytes. Since the main distinction between these forms is basically revealed with coloration differences, with macrogametocytes generally being more colored (AIKAWA; JORDAM, 1968), it is possible that gametocytes with coloring problems or in intermediate stadia of formation were not adequately identified (VAN RIPER III et al., 1994; AIKAWA; JORDAM, 1968; GARNHAM, 1966). With this, there are two contrasting results: the isolates of $P$. juxtanucleare differ in form and size, as well as in some aspects of parasitism, but not differ in those characteristics related with the pathogenicity. The parasitism in all isolates was considered as moderate to low. Besides this, none of the birds involved in the experiment showed clinical symptoms of malaria. Souza (1998) and Elisei (2001) found the same results under experimental conditions. Santos-Prezoto et al. (2004) also found low parasitism in animals naturally infected with $P$. juxtanucleare, showing that low parasitism is not a exclusive consequence of experimental parasite inoculation. Together, these results corroborate the hypothesis that infection by $P$. juxtanucleare is an illness of secondary character due to an intrinsic limitation to the development of this parasite, which may be associated with its low virulence or an efficient host immune response (SANTOS-PREZOTO et al., 2004).

In this way it is interesting to note that $P$. juxtanucleare is part of the Novyella group, composed exclusively of species of Plasmodium known for low pathogenicity (BENNETT, 1970). Two alternative hypotheses can be invoked to explain the low variability in parasitemia and the low pathogenicity of $P$. juxtanucleare in G. gallus.

Supposing that the parasitemia is directly related to pathogenicity, the first hypothesis is exclusively adaptive, in the sense that highly virulent strains (with high parasitemia) tend to kill their hosts, with consequent elimination of the strain. On the other hand, strains with very low parasitism are not transmitted by vectors. Hence, natural selection would favor intermediate parasitemies. The second hypothesis is that the low parasitemia variability is an inherited characteristic of $P$. juxtanucleare ancestors (theoretically ancestors of the genus Novyella). A test of the second hypotheses would be to construct a phylogenetic species tree of Plasmodium using independent characteristics of the parasitemia measures, permitting measurement of the phylogenetic signal of this characteristic through comparative methods (which has been performed elsewhere). If an evident phylogenetic signal is detected, the first hypothesis is weakened, dispensing the need for new tests. If the phylogenetic signal is weak, the first hypothesis will be strengthened, which should then be tested more intensely.

\section{REFERENCES}

AIKAWA, M.; JORDAM, H. B. Fine structure of a reptilian malarial parasite. Journal of Parasitology, v. 54, n. 5, p. 1023-1033, 1968.

AKIBA, K. Studies on avian malaria. On the species of Plasmodium from chicken in Japan (P. japonicum Ishiguro, 1957 a synonym for $P$. juxtanucleare Versiani \& Gomes, 1941). Japan Veterinary Sciences, v. 21, n. 3, p. 18, 1959.

AL-DABAGH, M. A. Symptomatic partial paralysis in chicks with Plasmodium juxtanucleare. Journal Comparative Pathology, v. 71, n. 6, p. 217-221, 1961.

ALEXANDER, M. Why microbial predators and parasites do not eliminate their prey and hosts. Annual Review of Microbiology, v. 35, n. 2, p. 113-133, 1981.

BARRETO, M.P. Malária Aviária: III. Sobre o encontro de formas exoeritrocíticas do Plasmodium juxtanucleare Versiani \& Gomes, 1941. Hospital, v. 2, n. 4, p. 643-645, 1943.

BELTRÁN, E. Características de uma cepa mexicana (14B) de Plasmodium juxtanucleare Versiani \& Gomes, 1941. Revista del Instituto del Salubridad y Enfermedades Tropicales del Mexico, v. 4, n. 2, p. 265-272, 1943.

BENNETT, G.F.;WARREN, W. Biology of the Malaysian strain of Plasmodium juxtanucleare Versiani and Gomes, 1941. III. Life cycle of the erythocytic parasite in the avian host. Journal of Parasitology, v. 52, n. 3, p. 653-659, 1966.

DUBOS, R. Man adapting. New Haven: Yale University Press, 1965. $897 \mathrm{p}$.

ELISEI, C., SOUZA, P.C.A., MASSARD, C. L.; SOARES, C.O. Caracterización morfológica y morfométrica de Plasmodium juxtanucleare (Apicomplexa: Plasmodiidae). Parasitologia al dia, v. 25, n. 1-2, p. 12-18, 2001.

GARNHAM, P.C.C. Malaria parasites and other haemosporidia. Oxford: Blackwell Scientific Publication, 1966. $1114 \mathrm{p}$.

ISHIGURO, H. Plasmodium japonicum, a new species of malaria parasite pathogenic for the domestic fowl. Bulletim Faculty of Agriculture Yamaguti University, v. 8, n. 8, p. 723-732, 1957.

KRETTLI, A.U. Estudos sobre a prevalência, biologia e transmissão do Plasmodium juxtanucleare Versiani \& Gomes, 1941. 1971. 73f. Dissertação (Mestrado) - Universidade Federal de Minas Gerais, Belo Horizonte, 1971.

KRETTLI, A.U. Plasmodium juxtanucleare in the State of 
Minas Gerais, Brazil. Studies on its prevalence and some aspects of its biology. Revista do Instituto de Medicina Tropical de São Paulo, v. 14, n. 4, p, 235-245, 1972.

MANWELL, R, D. The problem of species, with special reference to the malaria parasites. Annais of Tropical Medicine, v. 30, n. 1, p. 435-439, 1936.

MANWELL, R. D. Malaria infections by four species of Plasmodium in duck and chicken, and resulting parasite modifications. American Journal of Epidemiology, v. 38, n. 3, p. 211-222, 1943.

MASSARD, C.L.; MASSARD, C.A. Aspectos biológicos do Plasmodium juxtanucleare Versiani \& Gomes, em aves do Brasil. Revista Brasileira de Medicina Veterinária, v. 4, n. 3, p. 3-24, 1981.

MASSARD, C.L. Aspectos biológicos de P. juxtanucleare (Haemosporidida: Plasmodiidae) em aves no Brasil. 1976. 51f. Dissertação (Mestrado) - Universidade Federal Rural do Rio de Janeiro, Itaguaí, 1976.

MASSARD, C.L. Caracterização do parasitismo por Plasmodium juxtanucleare (Haemosporidea: Plasmodiidae) em criação de Gallus gallus da raça Leghorn Branca. Arquivos da Universidade Federal Rural do Rio de Janeiro, v. 5, n. 2, p. 141-146, 1982.

MOTA, R.A.; CUNHA, E.L.P.; SOARES, C.; ALVES, L.C.; MASSARD, C.L. Variáveis hematológicas em Gallus gallus domesticus, Linnaeus, 1758, de criações rústicas da região metropolitana do Recife, naturalmente infectados com Plasmodium Noyella juxtanucleare Versiani \& Gomes, 1941. Ciência Veterinária nos Trópicos, v. 1, n. 1, p.176-180, 1998.

PARAENSE, W.L. Differences among some strains of Plasmodium juxtanucleare concerning the production of exorythrocytic forms in a single species of host. In: CONGRESSO INTERNACIONAL DE MICROBIOLOGIA, p.185, 1950, Rio de Janeiro. Anais..., Rio de Janeiro: CIM, 1950.

PLAMIERI, J.R. Be fair to parasites. Nature, v. 298, n. 5871, p. 220, 1982.

SANTOS- PREZOTO, H. H.; D’AGOSTO, M.; DAEMON, E. Prevalência e variação dos estádios eritrocíticos do Plasmodium (Novyella) juxtanucleare em Gallus gallus sob condições naturais, no período de um ano. Parasitología latinoamericana. v. 59, n. 1-2, p. 14-20, 2004.

SERRA FREIRE, N.M.; MASSARD, C. L. Plasmodium juxtanucleare Versiani \& Gomes, 1941 parasita de Gallus gallus L.; Meleagris gallopavo L. e Chysolophus ssp na região do Pantanal do Estado de Mato Grosso do Sul. Atas da Sociedade de Biologia, v.20, n. 1, p. 45-48, 1979.

SOARES, C.O.; FONSECA, A.H.; MASSARD, C.L.; SOUZA, P.C.A. Significância da malária aviária em Gallus gallus L. de criações rústicas. Revista Brasileira de Parasitologia Veterinária, v. 4 (Supl. 1), p. 201, 1995.

SOUZA, P.C.A. Malária Aviária: Parasitismo por Plasmodium (Novyella) juxtanucleare Versiani \& Gomes, 1941 em Gallus gallus L. de criações rústicas, nas mesorregiões do estado do Rio de Janeiro e aspectos clínicos e patológicos de sua infecção experimental. 137f. 1998. Tese (Doutorado) - Universidade Federal Rural Rio de Janeiro, Seropédica, 1998.

VAN RIPER III, C.; ATKINSON, C.T.; SEED, M.T. Plasmodia of birds. In: KREIER, J.P. (Ed. 2) Parasitic Protozoa. New York: Academic Press, 1994. p. 73-140.

VERSIANI, V.; GOMES, B.F. Sobre um novo hematozoário de galinha - Plasmodium juxtanucleare n. sp. (Nota prévia). Revista Brasileira de Biologia, v. 1, n.3, p. 231-233, 1941.

VERSIANI, V.; GOMES, B.F. Plasmodium juxtanucleare, parasita da galinha doméstica (Nota adicionais). Revista Brasileira de Biologia, v. 3, n.4, p. 113-117, 1943.
Received on January 17, 2007.

Accepted for publication on July 09, 2007. 